\title{
ONUS OF PROVING CONSENT IN TRESPASS TO THE PERSON: ON WHOM DOES IT REST?
}

After reviewing the law on the topic of consent to medical treatment, I have concluded that the actions of battery or negligence have always been available in Canada where a patient alleges unauthorized medical treatment. 1 There are, however, important theoretical and practical differences between the two which become critical in the face of recent cases which restrict the battery action. ${ }^{2}$ The onus of proof is one of the factors important in either action. Examining the battery action and consent to treatment, Canadian authority supports the position that in an action by a patient alleging battery as a consequence of unauthorized medical treatment, the onus of establishing a sufficient and effective consent rests on the defendant doctor. ${ }^{3}$ A well-known Canadian authority, Professor Linden (now Linden J.), comes to this conclusion in regard to consent in the medical context as well as to consent as a general defence to an intentional tort. He states that any earlier authority to the contrary is now "eclipsed". He notes that this makes the law of consent consistent with that of volenti non fit injuria and trespass because the onus is on the defendant in each. ${ }^{5}$

It cannot be denied that there exists a great disparity between Canadian and American jurisprudence on the topic of consent to medical treatment, ${ }^{6}$ including a difference in the principles of onus of proof. The English position on this issue depends primarily on an anomalous 97-year-old case where a housemaid was attempting to maintain an assault action against her employers and their doctor. ${ }^{7}$ This case would likely be decided differently in 1978, even in England, for there was no consent freely given.

However fascinating might be the history of the law in regard to consent, or the clarity of American jurisprudence as contrasted with the ambiguity of English jurisprudence, Canadian courts have placed the onus of proving consent on the doctor. This move is laudable because more complete evidence will be placed before the Court.

\section{E. Picard*}

1. E. Picard, "The Tempest of Informed Consent", Studies in Canadian Tort Law, Klar, ed., (1977) 129. See also Picard, Legal Liability of Doctors and Hospitals in Canada (1978).

2. Kelly v. Hazlett (1976) 1 C.C.L.T. 1 (Ont.), Reibl v. Hughes (1977) 78 D.L.R. (3d) 35 (Ont. H.C.). On appeal, a new trial was ordered: Brooke, J. A. Ont. C.A., June 18, 1978, unreported.

3. Schweizer v. Central Hospital (1974) 6 O.R. (2d) 606 (Ont. H.C.). Kelly v. Hazlett, supra n. 2, Reibl v. Hughes, supra n. 2.

4. Linden, Canadian Tort Law (1977) 58.

5. Id. at $\mathbf{5 5}$.

6. See Picard, supra n. 1 "The Tempest of Informed Consent".

7. Latter v. Braddell (1881) 50 L.J.Q.B. 488 (C.A.).

* Professor of Law, University of Alberta, Faculty of Law. 